\title{
Four perspectives on conservation in Africa
}

\section{Social assessment as a key to conservation success}

Large tracts of Africa still remain in a natural state and these areas offer potential for conservation. With this in mind, conservation biologists have used the best available data and techniques to identify priorities for safeguarding Africa's impressive biodiversity (Burgess et al., 2004). However, progress with implementing conservation actions remains slow, and much more is known about the 'where' than the 'how' of conservation in Africa.

At the root of this tardy progress is the failure of conservation scientists and practitioners, most of whom have biological backgrounds, to comprehend fully that achieving conservation goals is largely a matter of human choice. Most conservation research in Africa, as in most other parts of the world, is concerned with assessments of biological features. However, social issues and contexts (values, norms, institutions, organizations and human well-being), which underpin almost all of the opportunities and constraints for implementation, are accorded much less priority, if addressed at all (Knight et al., 2006). Sustainable conservation requires that biodiversity concerns be mainstreamed into the behaviour of individuals and organizations (Petersen \& Huntley, 2005) which, in turn, requires an understanding of these behaviours (Ehrlich \& Kennedy, 2005).

Our experience leads us to believe that a thorough assessment of the social context in a study area should be undertaken prior to, or at least in parallel with, the biological assessment. Such a social assessment should not be limited to demographic and land use data, as is the common practice, but should provide insights (spatially explicit where feasible) on, for example, developmental trends, socioeconomic determinants, stability and functioning of social organizations, and the environmental values held by the population concerned (Rietbergen-McCracken \& Narayan, 1998). While this may be standard practice in other sectors dealing with the sustainable use of natural resources (Sayer \& Campbell, 2004), it is certainly not so in the conservation sector.

The aim of a social assessment is three-fold. Firstly, it provides a description of the current interactions between the human society and its natural habitat as well as an estimate of future developments; thus, it delivers a clear description of the current and future pressures on the biodiversity targeted by conservation assessments. Secondly, it reveals opportunities for linking conservation actions synergistically with initiatives in other sectors that have strong support, thereby enabling the mainstreaming of conservation concerns. Thirdly, it provides a realistic assessment of institutional effectiveness and organizational capacity; deficiencies in this regard are major constraints acting on the implementation of conservation actions.

Social assessments have several other advantages. Firstly, they invariably involve the input of local experts whose participation can contribute substantially to support for the project. Secondly, an understanding of how humans interact with and value their natural environments enables the identification of those behaviours that need to be reinforced or changed to safeguard biodiversity. This, in turn, enables the targeting and framing of actions specific to stakeholders who are influential for conservation rather than, for example, launching an extensive and costly educational programme of uncertain effectiveness.

Understanding the social context of opportunities and constraints associated with conservation projects is, in our opinion, essential for the effective implementation of conservation actions. Just as systematic biological assessments represent a defensible approach for identifying strategic conservation priorities (the 'where' problem; Margules \& Pressey, 2000), social assessments provide the kinds of insights required to do conservation (the 'how' problem). The case has been repeatedly made for conservation science to embrace disciplines in the social sciences, most recently by Balmford \& Cowling (2006). Given the actual and potential conflicts between biodiversity and the imperatives of socioeconomic development in Africa, the need for incorporating social assessments into conservation projects is all the more urgent.

\footnotetext{
Richard M. Cowling and Angelika Wilhelm-Rechmann

Department of Botany

Nelson Mandela Metropolitan University

P O Box 77000, Port Elizabeth 6031, South Africa

E-mail rmc@kingsley.co.za
} 
References

Balmford, A. \& Cowling, R.M. (2006) Fusion or failure. The future of conservation biology. Conservation Biology, 20, 692-695.

Burgess, N., D'Amicio Holes, J., Underwood, E., Dinerstein, E., Olson, D., Itona, I., Schipper, J. \& Ricketts, T. (eds) (2004) Terrestrial Ecoregions of Africa and Madagascar. A Conservation Assessment. Island Press and WWF USA, Washington, DC, USA.

Ehrlich, P.R. \& Kennedy, D. (2005) Millennium assessment of human behaviour. Science, 309, 562-563.

Knight, A.T., Cowling, R.M. \& Campbell, B.M. (2006) An operational model for implementing conservation action. Conservation Biology, 20, 408-419.

Margules, C.R. \& Pressey, R.L. (2000) Systematic conservation planning. Nature, 405, 37-47.

Petersen, C. \& Huntley, B.J. (eds) (2005) Mainstreaming Biodiversity in Production Landscapes. Global Environment Facility, Washington, DC, USA.

Rietbergen-McCracken, J. \& Narayan, D. (1998) Participation and Social Assessment: Tools and Techniques. The World Bank, Washington, DC, USA.

Sayer, J.A. \& Campbell, B.M. (2004) The Science of Sustainable Development: Local Livelihoods and the Global Environment. Cambridge University Press, Cambridge, UK.

\section{Can biodiversity conservation be reconciled with development?}

For centuries African cultures coexisted with biodiversity but these ages are now long gone. The fast growing human population requires increasingly more resources, and reconciling the fulfilment of basic human needs with the conservation of biodiversity is now the major challenge for Africa. The historical perspective on this is that the continent's major protected areas were created at a time when African mammals appeared to face a bleak future. However, in many cases the creation of such areas involved the removal of people from their homelands and later, in the 1980s, it was found that these protected areas alone were insufficient to preserve biodiversity. Programmes intended to preserve biodiversity whilst serving economic needs were therefore introduced, and conservation programmes became ipso facto development programmes.

However, as conservation and development programmes started to fail, new methods were employed, such as a landscape approach (Sayer et al., 2006) and partnerships (McNeely, 1995), both of which relied on social mobilization to include previously excluded peoples in conservation activities (Adams \& McShane, 1996; Mutamba, 2004). Social mobilization expects local communities to participate in activities related to their natural resources but, in reality, this is not very different from the traditional conservation approach. Even with social mobilization people are invited to participate only in pre-defined projects; they are not necessarily encouraged to initiate projects and actions that affect their lives (Mutamba, 2004).

Empowering people is a long process best nurtured in a collective, cohesive and coherent social venture. However, such empowerment can lead to unexpected results because in Africa it often occurs without the full involvement of national governments (Mutamba, 2004). Of course, the other side of this is that African governments are often perceived as undemocratic, preventing local communities from exercising their rights. This is partly understandable, given the poor performance of many African governments on human rights and good governance. However, it is a fact that social mobilization will not work without functional states. Africans will only adopt sustainable management schemes through an empowerment process that makes them the true decision makers, and this will only be effective if African institutions become strong enough to implement the rule of law. In this sense, conservation success depends on both good governance and the engagement of local communities.

We still have a long way to go. In Central Africa, for example, many protected areas are still only 'paper parks', although at the same time these are the only places where there are still sizeable populations of wildlife (Eken et al., 2004). The strengthening and expanding of protected area networks in this region remains critical for halting the decline of biodiversity, and the promise of new protected areas under the aegis of La Commission de Forêt d'Afrique Centrale is welcome. However, this programme will not be successful unless it incorporates socioeconomic dimensions into the creation of new protected areas.

So, can biodiversity conservation be reconciled with development in Africa? Yes, but only if we acknowledge that sovereign, democratically elected governments must decide the course to take. The problem is not too much authority but the lack of authority, i.e. there are insufficient tools for good governance. Reconciliation of the fulfilment of basic human needs and the conservation of biodiversity depends on good governance, and this depends on the overall health of democracy.

\section{Bila-Isia Inogwabini}

WWF-DRC, BP 15.872 Kin 1

Kinshasa, Democratic Republic of Congo

E-mailbinogwabini@wwfcarpo.org

\section{References}

Adams, J.S. \& McShane, T.O. (1996) The Myth of Wild Africa: Conservation Without Illusion. University of California Press, Berkeley, USA. 
Eken, G., Bennun, L., Brooks, T.M., Darwall, W., Fishpool, L.D.C., Foster, M., Knox, D., Langhammer, P., Matiku, P., Radford, E., Salman, P., Sechrest, W., Smith, M.L., Spector, S. \& Tordoff, A. (2004) Key biodiversity areas as site conservation targets. Bioscience, 54, 1110-1118.

McNeely, J.A. (1995) Partnerships for conservation: an introduction. In Expanding Partnerships in Conservation (ed. J.A. McNeely), pp. 1-10. Island Press, Washington, DC, USA.

Mutamba, E. (2004) Community participation in natural resources management: reality or rhetoric? Environmental Monitoring and Assessment, 99, 105-113.

Sayer, J.M.A., Campbell, B., Petheram, L., Perez, M.R., Endandama, D., Dongmo, Z.-L.N., Defo, L., Mariki, S., Doggart, N. \& Burgess, N. (2006) Assessing environment and development outcomes in conservation landscapes. Biodiversity and Conservation, in press (DOI 10.1007/s10531006-9079-9).

\section{Challenges and partnerships in elephant con- servation and conflict mitigation}

Many people think of Africa as a cursed continent, experiencing natural catastrophes, poverty, hunger, civil strife and diseases on a greater scale than other continents. In seeming contrast with this, Africa is noted for its range of biodiversity and habitats, and in particular for its relatively intact large mammal fauna. For many people this fauna is typified in particular by the African elephant Loxodonta africana, now recognized to consist of savannah $L$. africana africana and forest $L$. africana cyclotis subspecies across 32 range states. The problems facing elephant conservation also typify many of the challenges facing conservation in Africa.

Elephants range over wide areas and when, following the 1990 ban on the ivory trade, elephant populations began increasing, they started to re-establish in their former ranges. This led to increases in human-elephant conflict and, coupled with habitat loss and poaching, poses a serious challenge to efforts to conserve elephants in Africa. The measures employed to minimize conflict proved to be expensive and failed to work in many situations. Novel mitigation measures, including alternative planting regimes, economic incentives, earlywarning systems, deterrents, communal guarding and the use of bees, have had varying degrees of success (O'Connell-Rodwell et al., 2001; Karidozo \& Osborn, 2005; Parker \& Osborn, 2006; Sitati \& Walpole, 2006). In yet a further complication, the failure of governments to address the question of problem elephants adequately results in increased animosity towards the species.

Mitigating human-elephant conflict strategically is important not only for increasing local support for conservation and reducing the killing of elephants but from a moral perspective. The future of elephant conservation lies in identifying appropriate mitigation methods that can both improve local tolerance of elephants and provide communities with tangible benefits from elephant conservation. However, poor governance of funds destined for affected communities creates resentment and discourages local efforts to manage elephants. In addition, outdated or non-existent national policies and legislation often stymie efforts to mitigate human-elephant conflict. Across Africa variations in poaching intensity and human-elephant conflict, localized overpopulation of elephants, and differences in wildlife policy and legislation make it difficult to take common approaches towards elephant conservation. For instance, while the southern African countries have large populations of elephants, stock piles of ivory and low degrees of human-elephant conflict, the converse is true for eastern and central African countries. There are concerns, for example, that any attempt to open up the ivory market for southern African countries could instigate poaching in East Africa.

Studies of human-elephant conflict have recommended simple, community-based methods of conflict mitigation. However, to remain effective, combinations of methods must be used. In addition, comprehensive land use planning, both locally and nationally, can go a long way towards reducing conflict. Zoning helps to maintain elephant migration by ensuring connectivity between main elephant ranges and creating buffer zones between cultivated areas and elephant refuges. Community-based wildlife management schemes offer potential for improving local livelihoods, improving attitudes and tolerance towards elephants. However, political instability and insecurity can disrupt elephant conservation and implementation of mitigation strategies for human-elephant conflict. A partnership approach to ameliorate conflicts with elephants and improve elephant conservation is therefore of paramount importance.

The centrality of partnerships in elephant conservation and management has been expressed in recent policy statements at both the international and national levels (Walpole et al., 2006). Partnership involves working interactively on the management of problem elephants through a multisectoral or integrated approach. Typically, this involves working together to share lessons and expertise and finding common solutions across the elephant range states, including pooling of financial resources within a network of elephant practitioners. These undertakings can produce consensus and creative synergy, leading to new opportunities, innovative solutions, and a greater level of effectiveness in elephant management. To ensure lasting political support for elephants it is also necessary to develop more effective tools to communicate elephant conservation challenges to politicians and decision makers, thus simultaneously 
addressing the various technical, socioeconomic and political issues at different sites and levels.

Noah Sitati

Durrell Institute of Conservation $\mathcal{E}$ Ecology

University of Kent, Canterbury, Kent, CT2 7NS, UK

E-mail n_wasilwa@hotmail.com

\section{References}

Karidozo, M. \& Osborn, F.V. (2005) Can bees deter elephants from raiding crops? An experiment in the communal lands of Zimbabwe. Pachyderm, 39, 26-32.

O'Connell-Rodwell, C.E., Rodwell, T., Rice, M. \& Hart, A. (2000) Living with the modern conservation paradigm: can agricultural communities co-exist with elephants? A five-year case study in East Caprivi, Namibia. Biological Conservation, 93, 381-391.

Parker, G.E. \& Osborn, F.V. (2006) Investigating the potential for chilli Capsicum spp. to reduce human-wildlife conflict in Zimbabwe. Oryx, 40, 343-346.

Sitati, N.W. \& Walpole, M.J. (2006) Assessing farm-based measures for mitigating human-elephant conflict in Transmara District, Kenya. Oryx, 40, 279-286.

Walpole, M., Sitati, N., Stewart-Cox, B., Niskanen, L. \& Stephenson, P.J. (2006) Mitgating human-elephant conflict in Africa: a lesson-learning and network development meeting. Pachyderm, 41, 95-99.

\section{A new perspective on the Sahara}

What I love about deserts is their uncluttered perfection. When the sand and dust have settled you can generally see what's going on. The Sahara is one of those magical places where life in all its incredible diversity looks out unimpeded on the infinity of space. Ten million square kilometres of what some would have us believe is a barren, waterless wasteland of scalding rock and sand. Sure, there's plenty of that but it would be short-sighted to write off deserts as irrelevant to modern day conservation. Recent research has even shown that Saharan dust plays a significant role in the fertility of the Amazon basin (Koren et al., 2006). Lack of water does not mean lack of life but the presence of more exquisite forms of it. As the late defender of deserts and inveterate wilderness crusader, Edward Abbey (1968) wrote: 'There is no shortage of water in the desert but exactly the right amount, a perfect ratio of water to rock, of water to sand, insuring that wide, free, open, generous spacing among plants and animals'. Exactly!

What the conservation community chooses to conserve is often a matter of perspective and personal preference, where far too often the qualitative is overlooked in favour of glamour or numbers. Are the desert ecosystems that maintain productive communities of highly adapted arid land plants and animals any less perfect and less valuable than those of coral reefs and rainforests? But it's not just in the numbers game that areas such as the Sahara fall foul of richness based systems of triage, it is also often a matter of ignorance and lack of awareness. I always like to question professional conservation audiences about recent large mammal extinctions. To date not one has identified the poor old scimitar-horned oryx, last seen in the wild in the 1980s and listed as Extinct in the Wild on the IUCN Red List. Nor do they know about the other antelopes and gazelles on the brink of suffering the same demise. The addax and the dama and slender-horned gazelles are all down to global populations in the low hundreds. Although overhunting is by far the most important factor, a cocktail of secondary threats, including periodic drought, habitat encroachment and a chronic lack of resources for conservation, also contribute.

Although 2006 was the International Year of Deserts and Desertification (Fisher, 2006), I am not sure that, beyond a couple of useful publications (UNEP 2006a,b), a great deal changed or was accomplished. Was significantly more money spent on desert conservation issues? Was greater awareness raised of deserts and their multiple values to the 500 million people that live there? If anything, deserts were further vilified and the conservation issues clouded by the not unexpected emphasis on desertification, a process of largely man-made land and natural resource degradation taking place at the desert's edge.

It was because of the largely silent crisis of extinction facing desert wildlife that the Sahara Conservation Fund (SCF; http:/ /www.saharaconservation.org) was established in 2004. With a programme based on in situ conservation, reintroduction, and raising awareness of Saharan conservation issues, progress is being made. Especially heartening is the interest and support coming from the zoo community. As custodians of what may soon become the last addax or dama gazelles alive, zoos like St Louis, San Diego, Hanover and Marwell are supporting SCF in bringing species such as the scimitar-horned oryx back to countries from which they have disappeared. Also comforting is the fact that local NGOs, activists and scientists are joining forces to lobby their governments for a more responsible and proactive approach to dealing with chronic disrespect for wildlife and wildlife legislation. Action against the totally unsustainable activities of foreign hunting parties by groups such as SOS Faune du Niger and Chad's APROCOFF are gradually reaching their targets and deserve our fullest support.

As elsewhere, successful conservation in deserts cannot be achieved without incentives or without the support of the governments and people with whom the wildlife and other natural resources live and fare for better or worse. Nor is the Sahara any different from other places beggared by warfare, corruption and lack of resources. It is 
blatantly obvious to the Sahara's traditional land users that desert wildlife and the sparse, far-flung but productive ephemeral grasslands are important for their survival. Many recognize the role that wildlife plays in the fight against desertification and the germination and maintenance of plant communities. Others content themselves with more mystical but nonetheless powerful concepts. If there were no addax in the desert then why would Allah, in all His wisdom, bring rain to such desolate places? To paraphrase William Trogdon (1983), it is all a matter of perspective: 'To say nothing is here is incorrect; to say the desert is stingy with everything except space and light, stone and earth is closer to the truth'.

\section{John Newby}

Sahara Conservation Fund, Route de Begnins 9 A

1196 Gland, Switzerland

E-mail john.newby@bluewin.ch

\section{References}

Abbey, E. (1968) Desert Solitaire. McGraw-Hill, New York, USA. Fisher, M. (2006) Don't desert drylands. Oryx, 40, 1-2.

Koren, I., Kaufman, Y.J., Washington, R., Todd, M.C., Rudich, Y., Vanderlei Martins, J. \& Rosenfeld, D. (2006) The Bodélé depression: a single spot in the Sahara that provides most of the mineral dust to the Amazon forest. Environmental Research Letters, 1, (5 pp.), doi /10.1088/1748-9326/1/1/ 014005.

Trogdon, W. (1983) Blue Highways. Little, Brown and Company, Boston, USA.

UNEP (2006a) Global Deserts Outlook. United Nations Environment Programme, Nairobi, Kenya [http:// www.unep.org/geo/GDOutlook/, accessed 22 March 2007].

UNEP (2006b) Tourism and Deserts: A Practical Guide to Managing the Social and Environmental Impacts in the Desert Recreation Sector. United Nations Environment Programme, Paris, France [http://www.unep.fr/pc/ tourism/library/Desert\%20Guide.htm, accessed 22 March 2007]. 